\title{
Analysis of Mathematical Representation Process Standard in Learning Mathematics on Relation Concept
}

\author{
Fashihah \& Abd. Qohar ${ }^{(*)}$ \\ Mathematics Department, Universitas Negeri Malang \\ Jl. Semarang 5 Malang, Indonesia
}

\begin{abstract}
Received: November 25, 2019 Representation is the interpretation of students' thinking to a problem in Revised: June 05, 2020

Accepted: June 24, 2020 the form of words or verbal, text, tables, graphs or symbols of Mathematics as an aid instrument to solve problems. Representation is an important standard process in Mathematics learning. There are 3 representation standard processes in learning. One of the materials that require the ability of representation at junior high school level is relation. This study is aimed at describing the mathematical representation standard process in learning Mathematics in the material of relation. This study employed a qualitative approach of descriptive research. The procedures conducted in this study were (1) designing learning instruments, (2) implementing learning design in peer teaching, (3) conducting learning analysis related to the abilities. The results of the study show that the first standard process is seen in apperception activity, Activity 1 on LKS (student's worksheet), Activity 2 on LKS (student's worksheet), group presentations and exercises. Moreover, the second standard process is seen prominently in the exercise activities, while the third standard process is seen prominently in Activity 2 on LKS (student's worksheet). Based on the results of the study, it can be concluded that the three standard processes have been seen in almost all learning activities.
\end{abstract}

Keywords: mathematical representation, relation, standard process

(*) Corresponding Author: $\quad$ Email: abd.qohar.fmipa@um.ac.id, Phone number: (+62)81555600400

How to Cite: Fashihah \& Qohar, A. (2020). Analysis of mathematical representation process standard in learning mathematics on relation concept. Formatif: Jurnal Ilmiah Pendidikan MIPA, 10 (2): 115-124. http://dx.doi.org/10.30998/formatif.v10i2.5259

\section{INTRODUCTION}

Mathematics learning prepares students to face problems in Mathematics and in real life. In Mathematics learning, there are various standard processes that students must have. According to NCTM (2000), the standard processes of Mathematics learning are: (1) problem-solving, (2) reasoning and verification, (3) communication, (4) connections and (5) representation. One of the purposes of learning Mathematics in the 2013 Curriculum is that students are expected to have the ability of mathematical representation. It is written on the Regulation of the Minister of Education and Culture No. 58 of 2014. The above statement is also in line with Mathematics learning standards set by NCTM, which states that one of the abilities that students need to master and to develop is the ability of representation (NCTM, 2000).

Representation is one of the important abilities that students need to have. This is in line with the opinion of NCTM (2000) which states that representation is the core of Mathematics learning. The ability of representation is one of the basic abilities used to connect abstract ideas and logical thinking so that an understanding of Mathematics is obtained (Widakdo, 2017). Students can develop and deepen their understanding of 
mathematical concepts and relate them to how to create, to compare, and to use various representations. Also, Dahlan, et. al. (2011) adds that representation in Mathematics learning is important as a foundation or a basis for students to understand and to use mathematical ideas that they have in solving a problem. Meanwhile, Booth, et. al. (2013) argues that representation is something important to solve mathematical problems. According to Goldin (2002), representation is a configuration that can present something in another form, for example, a word can represent a real-life object, a number can represent the size of a person's body weight or the position of a dot on a number line. Furthermore, Hwang, et. al. (2007) interprets the representation as the relationship between objects and symbols. Kalathil, et. al. (2000) state that representation is an effort made by students to show the results of their work in solving a problem. Furthermore, Gagatsis \& Elijah (2004) suggest that representation is a configuration of images or real objects that presents something in another form. Based on several opinions above, it can be concluded that representation is an interpretation of students' thoughts on a problem in the form of words or verbal words, tables, graphs, or mathematical symbols as the instruments to solve problems.

NCTM sets five standard processes that students must have, namely problem solving, reasoning, communication, connections and representation. Representation is one of the five standard processes covered by NCTM. The five standard processes cannot be separated from Mathematics learning as all of them are interlinked in the Mathematics teaching-learning process (Syafri, 2017). The standard process of representation emphasizes the use of symbols, charts, graphs, and tables in connecting and in expressing mathematical ideas (Walle, 2010). It shows that representation is one of the standards that must exist in Mathematics learning. The standard process of mathematical representation set by NCTM consists of creating and using representations to organize, to record and to communicate mathematical ideas; selecting, applying and translating among mathematical representations to solve problems; using representations to model and to interpret physical, social and mathematical phenomena (Walle, 2010).

According to NCTM (2000), the first standard process of representation is creating and using representation to organize, to record and to communicate mathematical ideas. The second standard is selecting, using and translating various mathematical representations to solve problems, and the third standard process is using representations to create models and to interpret mathematical, physical and social phenomena.

The first standard process is creating and using representations to organize, to record and to communicate mathematical ideas. Students should be able to write mathematical representation ideas which are the important parts of Mathematics. According to NCTM (2000), it is important to improve students' abilities in representing ideas in the way they have. Communicating mathematical ideas really requires an external representation in the form of written symbols, images or physical objects (Hudiono, 2010). It is in line with McCoy (1996) who suggests that the best way to help students understand Mathematics through representation is by encouraging them to find and to create a representation as an instrument and a way of thinking in communicating mathematical ideas. This is in accordance with the first standard process of representation, that is, students can use representations to facilitate them in communicating ideas.

The second standard process is selecting, applying and translating various mathematical presentations to solve problems. Students can state a statement in various forms of representations (NCTM, 2000). A form of representation has weaknesses and strengths, so students can use the form of representation in accordance with their needs. The selection of the representation model that is owned by students plays an important role in decision making strategies for solving problems that are appropriate and accurate 
(Hudiono, 2010). In addition, Hutagaol (2013) states that someone needs to represent a variety of ways to think mathematically and to communicate mathematical ideas. Based on this result, it can be concluded that the second standard process of representation, namely selecting and applying the form of representation to solve important problems to be raised in mathematics learning.

The third standard is using or applying representations to create the model and to interpret mathematical, physical and social phenomena. According to NCTM (2000), the use of representations for students to model physical, social, and mathematical phenomena must grow from year to year. In addition, Mathematics learning needs to be connected with mathematical, physical and social phenomena so that students can realize the use of Mathematics in a wide range. According to Hutagaol (2013), contextual learning can improve the ability of mathematical representation. In addition, Ahmad, et. al. (2010) also state that the process of translating situations into mathematical forms is one of the difficulties experienced by students, so they need to be trained in the learning process. The statement above indicates that the third standard process of representation is important to be emerged in Mathematics learning.

One of the junior high school Mathematics materials that require representation ability is about relations material. Based on the enclosure of the Minister of Education and Culture Regulation No. 24 of 2016 class VIII, there are basic competencies, namely: 3.3 Describing and stating relations and functions using various representations (words, tables, graphs, diagrams and equations); and 3.4 Solving problems related to relations and functions using various representations. In this study, researchers take relations material, specifically about how to present relations.

This article is focused on the analysis of the standard process of mathematical representation in Mathematics learning in relations material. Therefore, the researchers conducted a research under the title "Analysis of Standard Process of Mathematical Representation in Mathematics Learning in Relation Concept".

\section{METHODS}

This research used a qualitative approach. According to Creswell (2012), qualitative research is aimed at uncovering a problem and developing it in detail to understand the phenomena centre of a problem. The type of this research was descriptive. The main purpose of descriptive research is to provide an accurate description, a status description or a characteristic of a situation and phenomena (Johnson \& Cristensen, 2004). In line with the purpose of descriptive qualitative research, the purpose of this study was to describe the standard representation process in Mathematics learning in relations material. The procedures of this study were as follows: (1) designing learning instruments, (2) implementing learning designs in a peer teaching, and (3) conducting an analysis of learning associated with the representation standard process. The research procedure will be explained in details as follows.

The first stage was designing learning instruments in the form of lesson plans and student's worksheets. The designed lesson plans were cooperative learning based lesson plans. At the beginning of learning activities, the teacher made an apperception to remind students of the prerequisite material before learning how to present relations. The prerequisite material in the lesson plan was: writing down members of a set and determining the location of a point on the Cartesian diagram. Furthermore, students in one class were formed into 3 heterogeneous groups. Each group consisting of 3-4 students got different worksheets. After each group finished working on the worksheet, representatives of each group were asked to present the results of their group discussions. 
Next, students were asked to do the exercises to measure their understanding of the material being taught.

Group 1 got a worksheet of the way of presenting relations using an arrow diagram. Group 2 got a worksheet of the way of presenting relations using a Cartesian diagram, and group 3 got worksheet of the way of presenting relations using a set of sequential pairs. Each worksheet consisted of two activities and exercises. In Activity 1, students were required to be able to present relations using the way of presentation according to the worksheet they had obtained. Students working in groups wrote down the names of members and favourite foods of each group member in the table provided. After that students were asked to present the problems in the table using the method of representation in accordance with the worksheet they got. Students were guided to be able to represent relations by following the steps in the worksheets. In Activity 2 (Group Projects) a problem related to physical phenomenon was presented, namely the phenomenon of waste of water tap in daily life. In this activity, students were required to be able to present the problems provided by using the relations presentation in accordance with the worksheet they had obtained. The question exercise consisted of one question, in the form of a story about relations presentation. In this activity, students were expected to be able to choose the way of presenting relations to answer the problems in the exercises.

The second stage was implementing learning design in peer teaching. Learning instruments that had been designed were then implemented in learning. Peer teaching was attended by 2 males and 8 females who acted as students. At this stage, each group was asked to do the worksheet that had been designed and to provide exercises about the ability of mathematical representation at the end of learning.

The third stage was conducting a learning analysis related to the representation standard process. The researchers conducted learning analysis when learning took place and was based on the learning outcomes in the worksheet to describe the standard process of mathematical representation in learning.

\section{RESULTS \& DISCUSSION}

Peer teaching in this study begins with praying and preparing students to be ready to participate in learning. After all, the students in the class are ready to take part in learning. The teacher provides apperception and motivation to students so that they are enthusiastic in learning. All learning activities run smoothly and almost every activity involves representation standard process.

According to NCTM (2000), there are 3 standard processes of mathematical representation. Standard representation emphasizes the use of symbols to model mathematical ideas (Walle, 2010). At the time of apperception, the questions are presented on the Power Point. Then students are asked to answer the questions on the Power Point and write the answers on the board. Based on the learning that had been carried out, it is obtained that when apperception appears, students can write down members of a set.

In Figure 1, it can be seen that students create and use representation to answer questions given by the teacher about the set members. Students use the representation to communicate the ideas they have to others. Based on the analysis of researchers, the standard process of representation has emerged in the first process, according to NCTM (2000), that is, creating and using representation to organize, to record and to communicate mathematical ideas. 


\section{Perhatikan gambar berikut.}

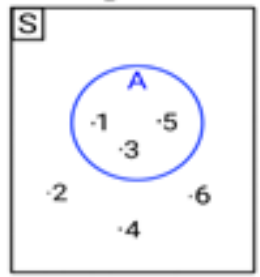

Tuliskan anggota himpunan dari $\mathrm{A}$ dan $\mathrm{S}$.



Figure 1 Writing Members of Set

At the time of apperception, students can also represent the location of the coordinate points on the Cartesian diagram according to Figure 2. According to Walle (2010:4), visual aids such as charts and graphs must be understood by students to communicate mathematical ideas. This is in line with Figure 2; students use graphical representations to communicate their mathematical ideas. Therefore, it can be concluded that in this activity, the first standard representation process emerged are creating and using representations to organize, to record and to communicate mathematical ideas.

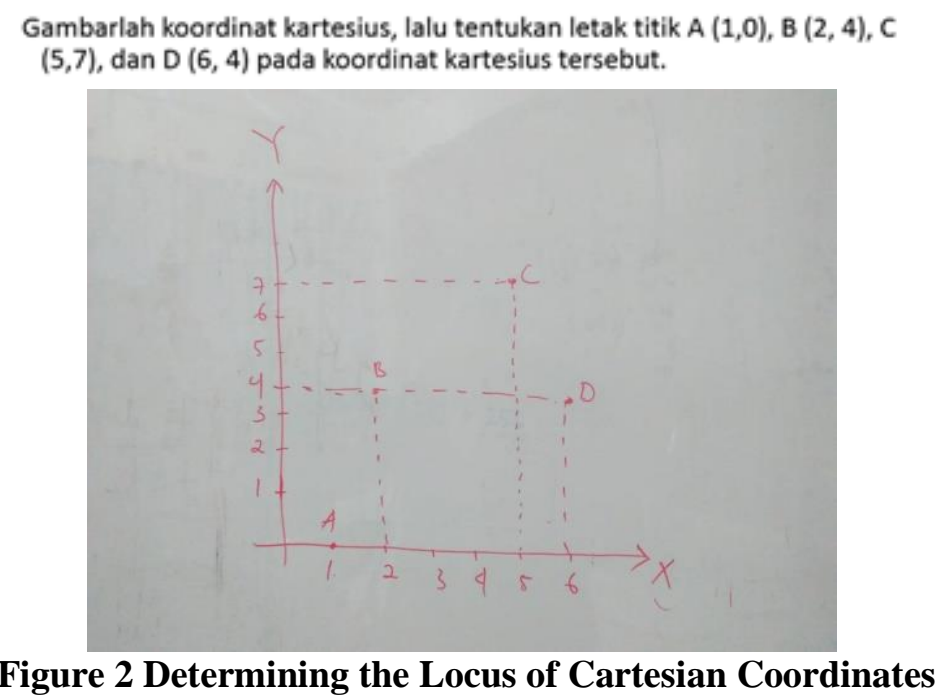

At the core activity, namely in LKS or in worksheet Activity 1, it can be seen that students can use representations in the form of a table according to Figure 3. The use of a table can facilitate students to record and to communicate mathematical ideas. In this activity, the first representation of standard process emerged is in accordance with NCTM 
(2000), that is, creating and using representation to organize, to record and to communicate mathematical ideas.

Tulislah nama anggota kelompok kalian serta makanan favorit mosing-masing anggota kelompok pada tabel berikut ini.

\begin{tabular}{|l|l|}
\hline Himpunan Nama Siswa & \multicolumn{1}{|c|}{ Himpunan Makanan Favorit } \\
\hline \multicolumn{1}{|c|}{ Imancla } & Masi Kuning, Bakio \\
\hline Risna & Mie Ayam \\
\hline Ulva & Bakso \\
\hline & \\
\hline
\end{tabular}

Figure 3 Completing the Table

In addition, in Activity 1 step 2, students can use the representation of the way the relations are presented, which is in the form of an arrow diagram in accordance with Figure $4 \mathrm{a}$. Students understand the instructions in the worksheet appropriately so they can use representation according to the questions. In this activity, students use arrow diagrams to communicate mathematical ideas so that the first representation standard process appeared is creating and using representations to organize, to record and to communicate mathematical ideas. In line with the opinion of Kalathil (2010), representation is used by students to present mathematical cases that students think.

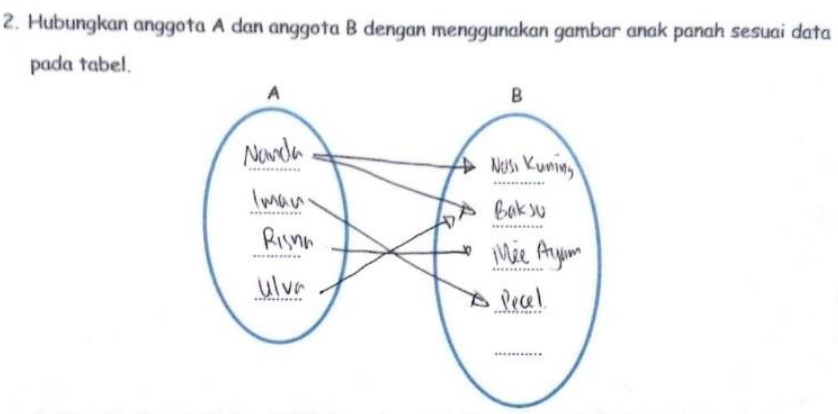

(a)
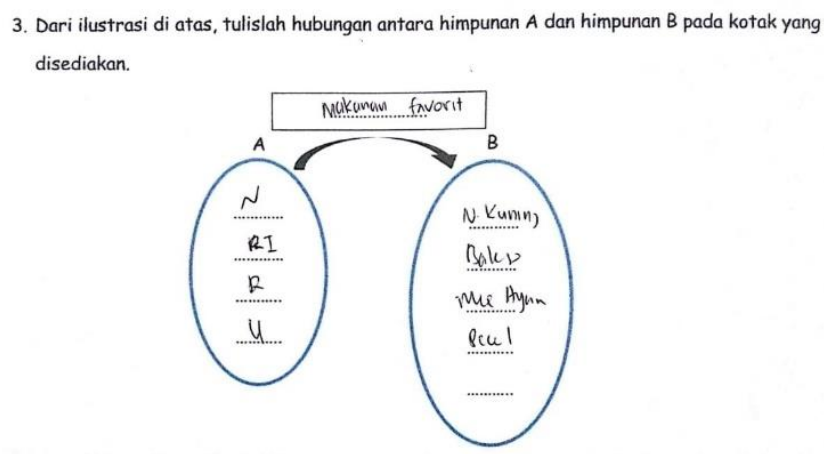

(b)

Figure 4 Arrow Diagram

There is a connection between the representation and the cognitive abilities of students (Stievenart, et. al., 2011). Students with a good mathematical understanding can represent a problem easily. Meanwhile, students with less good mathematical abilities have difficulty in representing a problem. In Figure 4b, Activity 1 step 3, students are incomplete in communicating their ideas. It shows that students do not provide arrows to 
connect domain members and codomain. In this activity students are expected to be able to use arrow diagrams to communicate mathematical ideas so that the first representations of standard process are emerged, that is creating and using representations to organize, to record and to communicate mathematical ideas. However, in Figure 4b, it appears that students use representations in the form of arrow diagrams but they are incomplete in representing their ideas.

In the worksheet of Activity 2, a problem related to physical phenomenon, namely the waste of tap water is provided. Students are asked to represent the relations of time and the amount of wasted water. The activity is in line with the statement of NCTM (2000) that the use of representation for students to model physical, social and mathematical phenomena must grow from year to year. As Hutagaol's statement (2013), contextual learning can improve the ability of mathematical representation. In Figure 5a, students use representation in the form of a table, while in Figure 5b, students use representation in the form of arrow diagrams to model the given physical phenomena. Therefore, the representation standard process seen in this activity is the first process standard, namely creating and using representations to organize, to record and to communicate mathematical ideas. The third standard process is to use representations to create models and to interpret mathematical, physical and social phenomena. Students create and use tables and arrow diagrams to communicate their ideas. Then they also use representations in the form of table and arrow diagram to interpret the given physical phenomena.

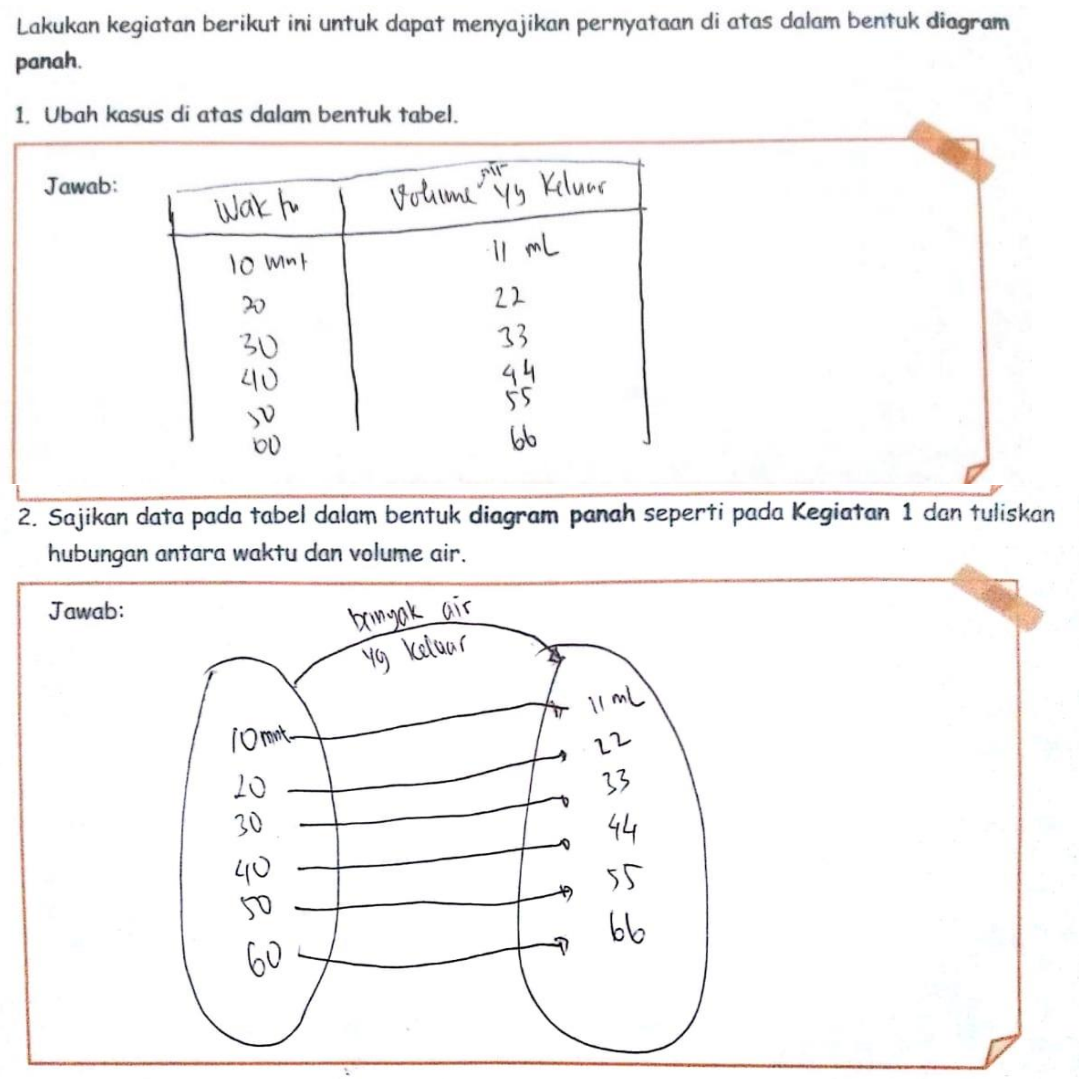

Figure 5 Modeling Physical Phenomena

In learning activities, students are asked to present the results of their group discussions. In the activity, students are expected to understand three ways of presenting relations. On the results of the students' work, it can be seen that students use 
representations in the form of table and arrow diagram and then they explain the results of their group discussions to classmates. In this activity, there is a process of communicating mathematical ideas to peers using arrow diagrams and tables as shown in Figure 6. According to Hudiono (2010), communicating mathematical ideas really requires an external representation in the form of written symbols, images or physical objects. Thus, it can be seen that in this activity, the first standard process namely creating and using representations to organize, to record and to communicate mathematical ideas emerges.

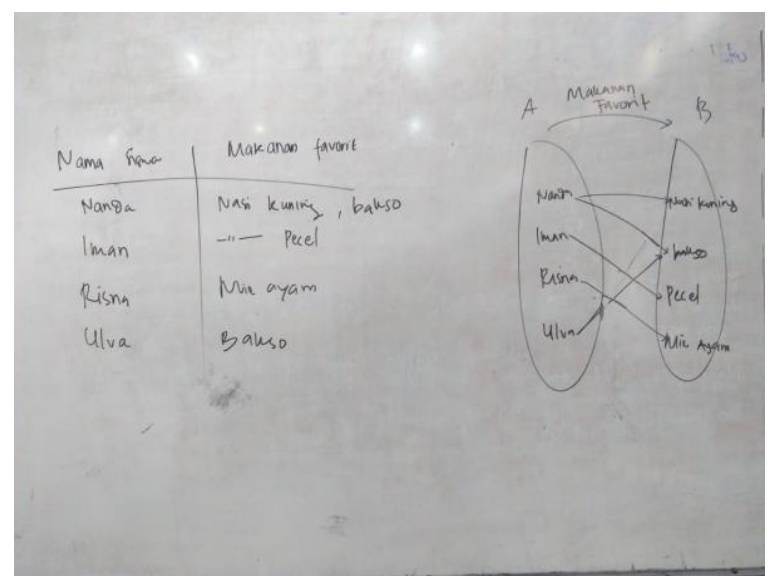

Figure 6 Using Representations in the Form of Arrows Diagram and Table

The next activity is Exercise. In this activity, a problem regarding to relations is provided. Students are asked to present a problem by choosing one way of presenting relations. In Figure 7, it can be seen that students choose to use the way of presenting relations in the form of a Cartesian diagram while in Figure 8 it can be defined that students use the way of presenting the relations they have chosen, namely Cartesian Diagram. In this activity, the prominent representation standard process is the second, namely selecting, using and translating various mathematical representations to solve problems. However, in this activity, the first process standard is also emerged, namely making and using representations to organize, to record and to communicate mathematical ideas. Indirectly, students use representation in the form of a Cartesian diagram to communicate their ideas. According to Widakdo (2017), by learning actively and fun in solving given problems, students are easier to represent and to connect each topic in Mathematics

1. Tulislah cara penyajian relasi yang akan kalian gunakan dalam menyelesaikan masalah di atas.

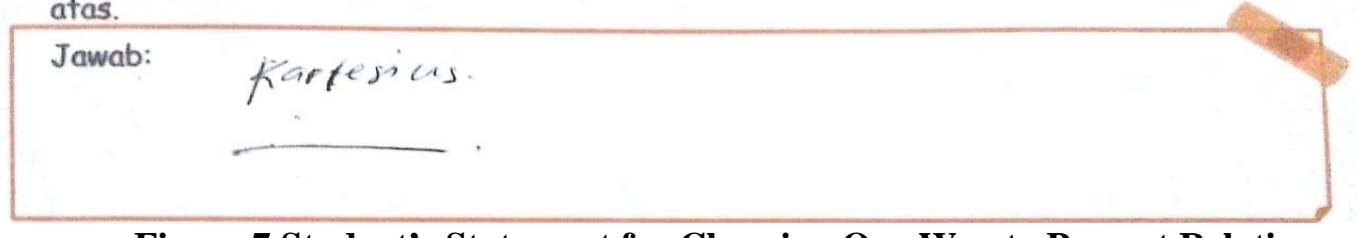

Figure 7 Student's Statement for Choosing One Way to Present Relations 


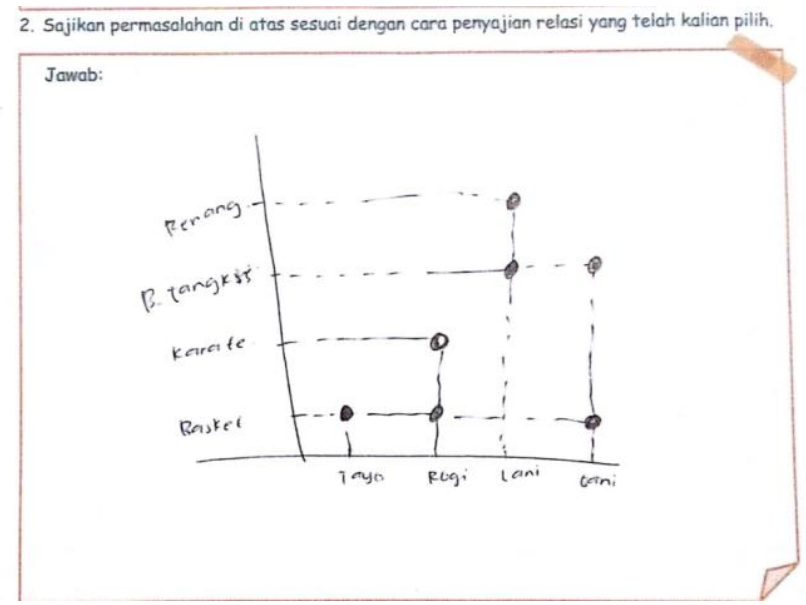

Figure 8 Student's Work Results in Exercise

From learning activities that have been implemented, it can be seen that the three representation standard processes have been seen in several activities. In fact, in several activities, two representation standard processes are emerged as explained above. These findings are in line with the findings of Widakdo (2017) which state that problem-solving activities can affect students' representational abilities.

\section{CONCLUSION}

In learning activities that have been carried out, it appears that the three standard representation processes have emerged. The first standard process, namely creating and using representations to organize, to record and to communicate mathematical ideas is seen in almost all activities, including apperception activities, Activity 1 on the worksheet, Activity 2 on the worksheet, group presentations and exercises. The second standard process namely selecting, applying and translating various mathematical representations to solve problems stood out as students worked on the exercises whereas the third standard process namely using representations to create models and to interpret mathematical, physical, and social phenomena is prominent in Activity 2 in the worksheet. This study aims at describing the standard process of representation, but is only limited on the way of presenting relations. The researchers hope that there will be further researches on the analysis of the representation standard process in other material or at the level of elementary, secondary or even undergraduate education.

\section{REFERENCES}

Ahmad, A., Tarmizi, A., Nawawi, M. (2010). Visual representation in mathematical world problem solving among form four students in malacca. Procedia Social and Behavioral Sciences, 8(5), 356-361. https://doi.org/ 10.1016/j.sbspro.2010.12.050

Booth, J. L., Davenport, J. L. (2013). The role of problem representation and feature knowledge in algebraic equation-solving. The Journal of Mathematical Behavior, 32, 415-423. https://doi.org/10.1016/j.jmathb.2013.04.003

Creswell, J. W. (2012). Research Design: Planning, Conducting and Evaluating Quantitative and Qualitative Research. Unites States of America: Person. 
Dahlan, J. A., Juandi, D. (2011). Analisis representasi matematik siswa sekolah dasar dalam penyelesaian masalah matematika kontekstual. Jurnal Pengajaran MIPA, $16(1), 128-138$.

Gagatsis, A., \& Elia, I. (2004). The effects of different modes of representation on mathematical problem solving. Proceedings of the 28th Conference of the International Group for the Psychology of Mathematics Education, 2, 447-454.

Goldin, A. G. (2002). Representation in Mathematical Learning and Problem Solving, in English, L. D (Ed) Handbook of International Research in Mathematics Education (pp. 197-201). Mahwah NJ: Laurence Erlbaum.

Hudiono, B. (2010). Peran pembelajaran diskursus multi representasi terhadap pengembangan kemampuan matematika dan daya representasi pada siswa SLTP, Jurnal Cakrawala Kependidikan, 8(2), 101-110.

Hutagaol, K. (2013). Pembelajaran kontekstual untuk meningkatkan kemampuan representasi matematis siswa sekolah menengah pertama. Jurnal Ilmiah Program Studi Matematika STKIP Siliwangi Banyuwangi, 2(1), 85-99. https://doi.org/10.22460/infinity.v2i1.p85-99.

Hwang, W., Cheng, N., Dung, J., Yang, Y. (2007). Multiple representation skills and creativity effects on mathematical problem solving using a multimedia whiteboard system. Education Technology \& Society, 10(2), 191-212.

Johnson, B., Christensen, L. (2004). Educational Research: Quantitative, Qualitative, and Mixed Approaches. New York: Pearson.

Kalathil, R. R., \& Sherin, M. G. (2000). Role of students' representations in the mathematics classroom. Fourth International Conference of the Learning Science, 27-28.

McCoy, L. P., Baker, T. H., \& Little, L. S. (1996). Using Multiple Representations to Communicate: An Algebra Challenge. In P.C. Elliot (Ed). Communication in Mathematics, K-12 and Beyond. Reston, VA: National Council of Teachers of Mathematics.

NCTM. (2000). Principles and Standards for School Mathematics. Reston, VA: NCTM.

Stievernart, M., Roskam, I., Muenier, J. C., Moortele, G.V.D. (2011). The reciprocal relation between children's attachment representations and their cognitive ability. Int. J. Dev., 58-66. https://doi.org/10.1177/0165025410370790

Syafri, F. S. (2017). Kemampuan representasi matematis dan kemampuan pembuktian matematis. Jurnal Pendidikan Matematika, 3(1), 49-55.

Walle, V.D., John, A. (2010). Elementary and Middle School Mathematics: Teaching Developmentally Seventh Edition. Boston: Pearson.

Widakdo, W. A. (2017). Mathematical representation ability by using project based learning on the topic of statistics. Journal of Physics: Conference Series, 1-7. https://doi.org/10.1088/1742-6596/895/1/012055 